\title{
Effects of interferon gamma on cultured synovial cells from patients with rheumatoid arthritis: inhibition of cell growth, prostaglandin $\mathrm{E}_{2}$, and collagenase release*
}

Hiroto Nakajima, Yoshio Hiyama, Wataru Tsukada, Haruaki Warabi, Shoji Uchida, Shun'ichi Hirose

\begin{abstract}
The effects of recombinant interferon gamma (rIFN $\gamma$ ) on the in vitro growth of adherent synovial fibroblast-like cells from patients with rheumatoid arthritis (RA) and also on the release of prostaglandin $E_{2}$ and collagenase from these cells stimulated with recombinant interleukin-1 $\beta$ (rIL-1 $\beta$ ) were investigated. The growth of adherent synovial cells from six of nine samples, determined by $\left[{ }^{3} \mathrm{H}\right]$ thymidine incorporation, was inhibited by rIFN $\gamma$ in a manner dependent on dose. The release of prostaglandin $E_{2}$ and collagenase from adherent synovial cells stimulated with rIL-1 $\beta$ was also suppressed by rIFN $\gamma$ in all samples tested, though the basal release of these inflammatory mediators was little influenced. No apparent correlation between inhibition of proliferation by rIFN $\gamma$ and either inhibition by rIFN $\gamma$ of rIL-1 $\beta$ stimulated prostaglandin $E_{2}$ release or the endogenous synthesis of prostaglandins was found.
\end{abstract}

Interferon gamma (IFN $\gamma$ ) has been shown to have antiproliferative, immunomodulatory, and antiviral properties. ${ }^{1-3}$ The ability of IFN $\gamma$ to induce and enhance the expression of class II major histocompatibility complex antigens on various types of cells is generally believed to be a factor in the pathogenesis of autoimmune disorders such as rheumatoid arthritis (RA). ${ }^{34}$

Research Institute, Daiichi Pharmaceutical Co Ltd, Tokyo H Nakajima Y Hiyama

W Tsukada

Division of Collagen

Diseases, School of Medicine,

Juntendo University, Tokyo

H Warabi

$S$ Hirose

Center for Rheumatic Diseases,

Tokyo Metropolitan

Hospital of Bokutoh,

Tokyo, Japan

$S$ Uchida

Correspondence to: Dr Hiroto Nakaiima,

Research Institute,

Daiichi Pharmaceutical

Co Ltd

16-13 Kita-kasai 1-Chome,

Edogawa-ku, Tokyo 134,

Japan

Accepted for publication

1 September 1989

*Presented in part at the 11 th

European congress of

rheumatology, Athens,

Greece, July 1987.

One of the features of RA is the hyperplasia of synovial lining cells and fibroblasts associated with the infiltration of lymphocytes and monocytes/macrophages into affected joints. Inflamed tissues of RA synovium release potent interleukin-1 (IL-1) activity, ${ }^{18-20}$ which in turn activates the synovial cells to generate large amounts of tissue degrading mediators, such as collagenase and prostaglandins. ${ }^{21} 22$ The role of IFN $\gamma$ in relation to these aspects of $\mathrm{RA}$, however, has not been fully investigated.

This study was designed to investigate the influence of $\mathrm{rIFN} \gamma$ on the in vitro proliferation of adherent synovial fibroblast-like cells from patients with RA and the release of prosta- glandins and collagenase from these cells stimulated with recombinant interleukin-1 $\beta$ (rIL-1 $\beta$ ). The results show the inhibitory effects of rIFN $\gamma$ on both cell proliferation and the rIL-1 $\beta$ induced release of prostaglandin and collagenase activity. These results suggest a further aspect of the regulatory role of IFN $\gamma$ in chronic inflammatory disease.

\section{Materials and methods}

SOURCE AND PREPARATION OF ADHERENT SYNOVIAL CELLS

Specimens of synovium were obtained at the time of synovectomy from the knee or hip joint of nine patients with classical or definite RA according to the American Rheumatism Association criteria. ${ }^{23}$ Patients who were taking more than $3 \mathrm{mg} /$ day of prednisolone or 300 $\mathrm{mg} /$ day of $\mathrm{D}$-penicillamine were excluded from the study. Adherent synovial cells were prepared from the synovium specimens essentially as has been described previously. ${ }^{24} 25$ Briefly, synovium was minced and dissociated enzymatically into a single cell suspension by treatment with bacterial collagenase (type I; Sigma Chemical Co, St Louis, MO, USA). The cells suspended in Dulbecco's modified Eagle's medium (Gibco, Grand Island, NY, USA) supplemented with $10 \%$ heat inactivated fetal calf serum (Gibco) and antibiotics (abbreviated as DMEM-FCS) were filtered through sterile gauze and plated at ca $10^{5} / \mathrm{cm}^{2}$ as primary cultures into $75 \mathrm{~cm}^{2}$ tissue culture flasks (Falcon 3024, Becton Dickinson and Co, Lincoln Park, NJ, USA). Adherent synovial cells were derived by trypsinisation $(0.25 \%$ trypsin $/ 0.02 \%$ EDTA) and passage (1:3 to $1: 4)$ in DMEM-FCS of the primary cultures. Most adherent synovial cells were morphologically fibroblast-like, in agreement with previous reports. ${ }^{25} 26$ The cells were used usually between the second and fourth passages.
rIFN $\gamma$, rIL-1 $\beta$, AND ANTISERUM TO rIFN $\gamma$

Recombinant interferon gamma $\left(3 \cdot 1 \times 10^{7}\right.$ antiviral $\mathrm{U} / \mathrm{mg}$ protein) from transfected $E$ coli and rabbit immune serum against $\operatorname{rIFN} \gamma$ were provided by Genentech (South San Francisco, CA, USA). Recombinant interleukin-1 $\beta$ (10 $\mathrm{U} / \mathrm{mg}$ ) was purchased from Genzyme (Boston, MA, USA).

$\left[{ }^{3} \mathrm{H}\right]$ THYMIDINE INCORPORATION ASSAY Adherent synovial cells obtained from the con- 
fluent cultures were plated into 96-well flat bottomed plates (Falcon 3072, Becton Dickinson and $\mathrm{Co}$ ) at $5 \times 10^{3}$ cells/well in $0.1 \mathrm{ml}$ of DMEMFCS. After two days of incubation at $37^{\circ} \mathrm{C}$ in a $5 \% \mathrm{CO}_{2}$ atmosphere the medium was removed and replaced with $0.1 \mathrm{ml}$ of fresh DMEM-FCS containing rIFN $\gamma$ or other agents, in triplicate, and incubated for an additional three days. Cultures were pulsed with $18.5 \mathrm{kBq}\left[{ }^{3} \mathrm{H}\right]$ thymidine (New England Nuclear, Boston, MA, USA) for the last 18 hours of incubation, and the incorporation of $\left[{ }^{3} \mathrm{H}\right]$ thymidine into DNA was assessed. ${ }^{27} 28$ Briefly, after medium aspiration cultures were trypsinised, harvested onto glass fibre filters with an automated harvester, and lysed by washing with distilled water. The DNA labelled with $\left[{ }^{3} \mathrm{H}\right]$ thymidine, trapped by the glass fibre filters, was counted by liquid scintillation spectrometry.

\section{PRELABELLED $\left[{ }^{3} \mathrm{H}\right]$ THYMIDINE RELEASE ASSAY}

The cytolytic potential of rIFN $\gamma$ was assessed by a slight modification of a method previously reported. ${ }^{29}$ Briefly, adherent synovial cells in the exponential growth phase were incubated in DMEM-FCS supplemented with $37 \mathrm{kBq} / \mathrm{ml}$ of $\left[{ }^{3} \mathrm{H}\right]$ thymidine for two days at $37^{\circ} \mathrm{C}$ in a $5 \% \mathrm{CO}_{2}$ atmosphere. After trypsinisation $5 \times 10^{3}\left[{ }^{3} \mathrm{H}\right]-$ thymidine labelled cells suspended in DMEMFCS were distributed into 96-well plates and incubated with rIFN $\gamma$ for one to three days. The cells were harvested onto glass fibre filters and the radioactivity remaining in the cells was counted as described above.

\section{DETERMINATION OF PROSTAGLANDIN $E_{2}$, 6-KETOPROSTAGLANDIN $F_{1 \alpha}$, AND THROMBOXANE $B_{2}$}

To measure prostanoid release rheumatoid adherent synovial cells were cultured as described previously. ${ }^{26}$ Briefly, $5 \times 10^{4}$ adherent synovial cells in $0.3 \mathrm{ml}$ of DMEM-FCS were placed in 24-well trays (Falcon 3047, Becton Dickinson and $\mathrm{Co}$ ) in duplicate. After two days of incubation at $37^{\circ} \mathrm{C}$ in a $5 \% \mathrm{CO}_{2}$ incubator the medium was removed and replaced with the same volume of fresh DMEM-FCS containing rIFN $\gamma$ either alone or in combination with rIL$1 \beta$, and incubated for an additional three days. Culture supernatants were harvested, pooled, and analysed for concentrations of prostaglandin $E_{2}$, 6-ketoprostaglandin $F_{1 \alpha}$, and thromboxane $\mathrm{B}_{2}$ by radioimmunoassay kits (New England Nuclear). Assays were performed in duplicate according to the manufacturer's instructions.

\section{COLLAGENASE ASSAY}

Three-day culture supernatants of adherent synovial cells, obtained as described above, were treated with $0.2 \mathrm{mg} / \mathrm{ml}$ of TPCK-trypsin (Sigma Chemical Co) at $25^{\circ} \mathrm{C}$ for 10 minutes, followed by soybean trypsin inhibitor (Sigma Chemical Co) and incubation for 10 minutes to convert the collagenase into its active form. ${ }^{24}$ Collagenase activity was measured in duplicate ${ }^{30}$ with fluorescein isothiocyanate labelled collagen (Cosmo Bio Co, Tokyo, Japan) as a substrate.
As fluorescein isothiocyanate is not released by trypsin in this assay any release of the isothiocyanate reflects actual collagenase activity. One unit of collagenase activity was defined as the amount of enzyme degrading $1 \mu \mathrm{g}$ of collagen/ min under the conditions used. ${ }^{30}$

\section{Results}

EFFECT OF rIFN $\gamma$ ON THE PROLIFERATION OF CULTURED ADHERENT SYNOVIAL CELLS FROM PATIENTS WITH RA

Isolated synovial fibroblast-like cells, obtained from nine different patients with RA, were cultured with various concentrations of $\mathrm{rIFN} \gamma$ for three days, and $\left[{ }^{3} \mathrm{H}\right]$ thymidine incorporation for the last 18 hours of incubation was determined. Figure 1 shows that $\left[{ }^{3} \mathrm{H}\right]$ thymidine incorporation in three-day cultures of six (patients 1, 2, 3, 4, 6, and 9) of nine samples was inhibited by rIFN $\gamma$ in a manner dependent on dose. The other three samples (patients 5, 7, and 8) showed only marginal response to rIFN $\gamma$ in three-day cultures. The data in fig 2 show

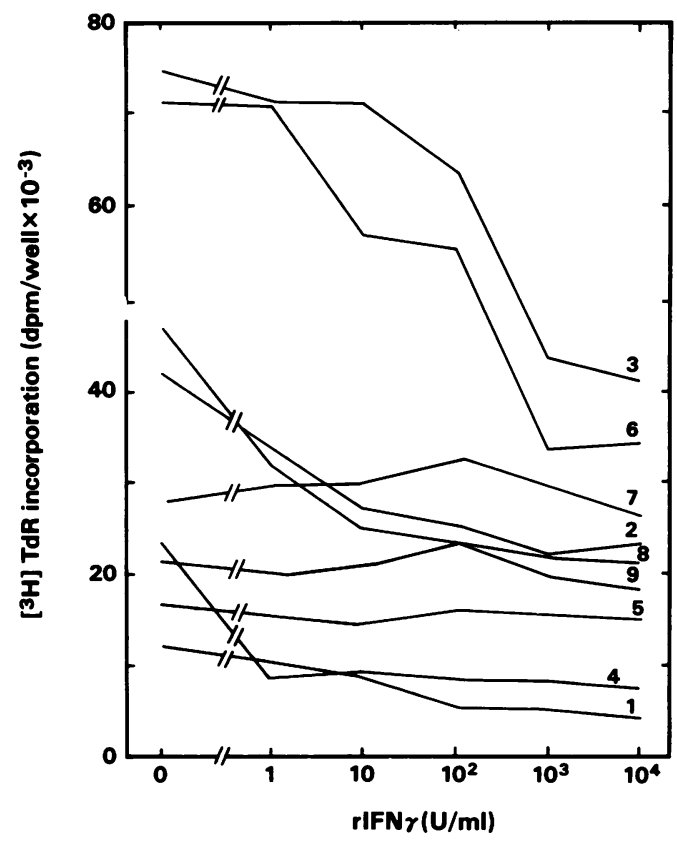

Figure 1: Effect of recombinant interferon gamma (rIFN $\gamma)$ on $\left[{ }^{3} H\right]$ thymidine $\left.\left({ }^{3} H\right] T d R\right)$ incorporation by adherent synovial cells from patients with rheumatoid arthritis. Triplicate cultures of adherent synovial cells were treated with rIFN $\gamma$ at concentrations of 1 to $10^{4}$ U/ml for three days, and were pulsed with $\left.{ }^{3} \mathrm{H}\right] \mathrm{TdR}$ for the last 18 hours of incubation. Patient number is indicated at the right.

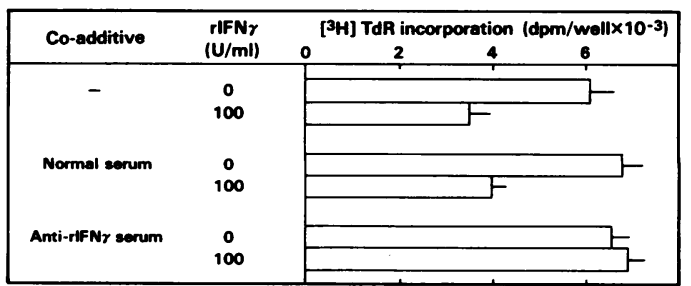

Figure 2: Effect of antibody to recombinant interferon gamma (anti-rIFNy) on the antiproliferative effect of rIFN $\gamma$. Triplicate cultures of adherent synovial cells from patient No 1 with rheumatoid arthritis were treated for three days with $100 \mathrm{U} / \mathrm{ml}$ of $r I F N \gamma$ in combination with either anti-rIFN $\gamma$ rabbit serum at 1/200 dilution or normal rabbit serum (I/200). Mean and SD are shown. $\left[^{3} \mathrm{H}\right] \mathrm{TdR}=\left[{ }^{3} \mathrm{H}\right]$ thymidine. 
that the antiproliferative effect of $\mathrm{rIFN} \gamma$ was abrogated completely by the coaddition of antibody to rIFN $\gamma$, confirming that IFN $\gamma$ is responsible for the inhibition of rheumatoid synovial cell proliferation. No direct cytolytic activity of rIFN $\gamma$ against synovial cells could be shown by using the prelabelled $\left[{ }^{3} \mathrm{H}\right]$ thymidine release assay as well as the trypan blue exclusion test (data not shown).

The following experiments were undertaken to examine the participation of endogenous prostaglandins in the antiproliferative effect of rIFN $\gamma$. As shown representatively in fig 3, neither the addition of $5 \mu \mathrm{g} / \mathrm{ml}$ indomethacin, a cyclo-oxygenase inhibitor, nor $0.03 \mathrm{ng} / \mathrm{ml}$ of rIL-1 $\beta$ to the culture influenced the antiproliferative effect of rIFN $\gamma$ against rheumatoid adherent synovial cells, though the basal rate of proliferation was sometimes modified, albeit marginally. As the amounts of prostaglandin released from the cells were drastically changed by the drugs (see below) these results indicate that inhibition of proliferation by rIFN $\gamma$ is not related to prostaglandin synthesis.

EFFECT OF rIFN $\gamma$ ON PROSTAGLANDIN $E_{2}$ RELEASE FROM CULTURED ADHERENT SYNOVIAL CELLS FROM PATIENTS WITH RA

The synovial fibroblast-like cells from patients with RA were cultured with rIFN $\gamma$ or rIL-1 $\beta$, or both, for three days, and prostaglandin $E_{2}$ concentration in the supernatant fluid was assayed. The solid lines in fig 4 show that basal concentrations of prostaglandin $E_{2}$ released spontaneously into the culture supernatants were very low and were little influenced by rIFN $\gamma$. The release of prostaglandin $E_{2}$ was increased 10 to 500 -fold, however, by stimulation with $\mathrm{rIL}-1 \beta(0.03-0.1 \mathrm{ng} / \mathrm{ml})$, and this stimulated release was reduced by between 45 and $85 \%$ by the coaddition of rIFN $\gamma$ in all samples tested, as shown by the broken lines in fig 4 . The extent of inhibition of rIL-1 $\beta$ stimulated prostaglandin $\mathrm{E}_{2}$ release by $\mathrm{rIFN} \gamma$ was compared with that of the inhibition of proliferation by rIFN $\gamma$ in each sample of adherent synovial cells, but no correlation was found.

Table 1 shows that rIFN $\gamma$ inhibited the rIL$1 \beta$ induced release of the other prostanoids measured-namely, 6-ketoprostaglandin $F_{1 \alpha}$ and thromboxane $B_{2}$, in a manner quantitatively

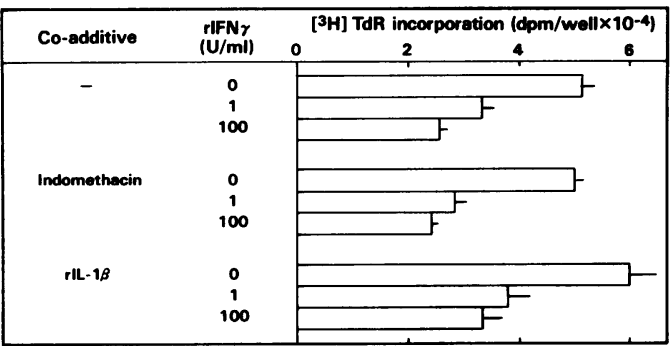

Figure 3: Effect of indomethacin and recombinant interleukin-1 $\beta(r I L-1 \beta)$ on the antiproliferative effect of recombinant interferon gamma $(r I F N \gamma)$. Triplicate cultures of adherent symovial cells from patient No 2 with rheumatoid arthritis were treated for three days with 1 or $100 \mathrm{U} / \mathrm{ml}$ of rIFN $\gamma$ in combination with either $5 \mu \mathrm{g} / \mathrm{ml}$ of indomethacin or $0.03 \mathrm{ng} / \mathrm{ml} \mathrm{rIL}-1 \beta$. Mean and SD are shown.

$\left[{ }^{3} \mathrm{H}\right] \mathrm{TdR}=\left[{ }^{3} \mathrm{H}\right]$ thymidine. similar to the inhibition of prostaglandin $E_{2}$ release.

EFFECT OF rIFN $\gamma$ ON COLLAGENASE RELEASE FROM CULTURED ADHERENT SYNOVIAL CELLS FROM

PATIENTS WITH RA

Collagenase activity, released in a latent form in the culture supernatants of adherent synovial cells, was determined after activation with trypsin. Spontaneous release of collagenase activity was almost negligible in all the cultures tested. In cultures of most cell samples, 0.03 $\mathrm{ng} / \mathrm{ml}$ of $\mathrm{rIL}-1 \beta$, which was adequate for stimulation of prostaglandin $E_{2}$ release, was insufficient to induce the release of collagenase

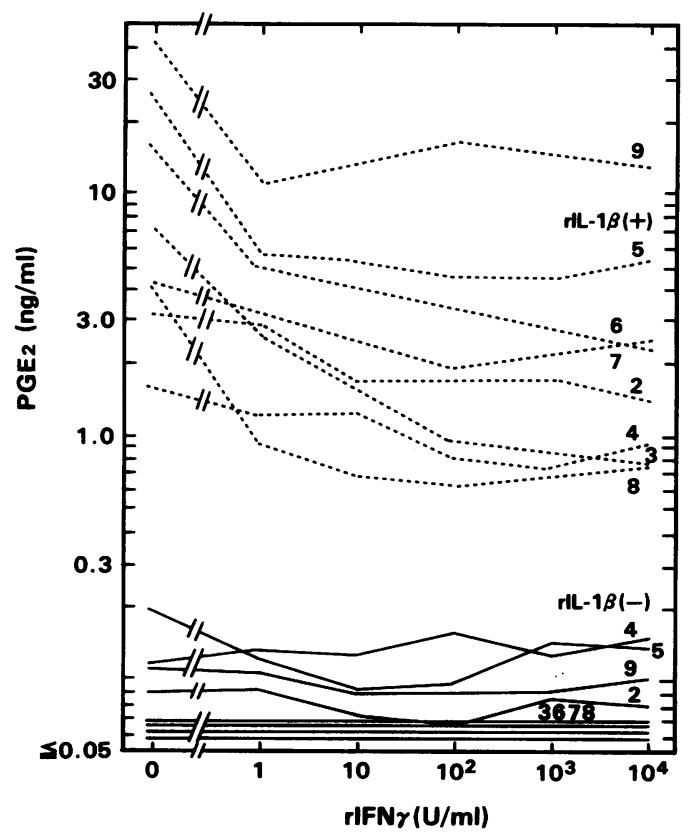

Figure 4: Effect of recombinant interferon gamma ( $I F N \gamma)$ on prostaglandin $E_{2}\left(P G E_{2}\right)$ release from adherent synovial cells from patients with rheumatoid arthritis. Duplicate cultures of adherent synovial cells were treated with rIFN $\gamma$ at concentrations of 1 to $10^{4} \mathrm{U} / \mathrm{ml}$ either alone (solid lines) or in combination with recombinant interleukin-1 $\beta(r I L-1 \beta)$ (broken lines; $0.03 \mathrm{ng} / \mathrm{ml}$ of $\mathrm{rIL}-1 \beta$ for samples from patients $2,3,4,7,8$, and 9 , and $0 \cdot 1 \mathrm{ng} / \mathrm{ml}$ of $r I L-1 \beta$ for samples from patients 5 and 6). After three days of incubation the culture supernatants were harvested and $P G E_{2}$ concentrations were determined as described in 'Materials and methods'. Mean of duplicate determinations is plotted. Agreement between duplicates was $\pm 15 \%$ of the mean. Numerals at the right are the patient numbers.

Table 1: Effect of recombinant interferon gamma (rIFN $\gamma$ ) on the recombinant interleukin-1 $\beta(r I L-1 \beta)$ induced release of prostaglandin $E_{2}\left(P G E_{2}\right)$, 6-ketoprostaglandin $F_{1 \alpha x}$ (6-keto $\left.P G F_{1 \alpha}\right)$, and thromboxane $B_{2}\left(T \times B_{2}\right)$ from (6-keto $\left.P G F_{1 \alpha}\right)$, and thromboxane
rheumatoid adherent synovial cells*

\begin{tabular}{lllll}
\hline $\begin{array}{l}r I L-1 \beta \\
(n g / m l)\end{array}$ & $\begin{array}{l}r I F N \gamma \\
(U / m l)\end{array}$ & \multicolumn{3}{l}{ Prostanoids released $(\mathrm{ng} / \mathrm{ml})$} \\
\cline { 3 - 5 } & & $P G E_{2}$ & $6-$ keto $P G F_{l a}$ & $T x B_{2}$ \\
\hline 0 & 0 & $0.2 \dagger$ & 0.4 & 1.7 \\
0.03 & 0 & 8.2 & 7.6 & 4.2 \\
0.03 & 1 & 4.9 & 4.3 & 1.6 \\
0.03 & 10 & 4.4 & 3.7 & 2.5
\end{tabular}

Adherent synovial cells from patient No 4 with rheumatoid arthritis were cultured with rIFN $\gamma$ or rIL-1 1 , or both for three arthritis were cultured with riFN $\gamma$ or riL-1 1 , or both for three days, and prostanoid concentrations in the culture supernatan were determined as described in 'Materials and methods'. $+V a l u e s$ are means of duplicate determination
between duplicates was $\pm 15 \%$ of the mean. 
Table 2: Effect of recombinant interferon gamma (rIFN $\gamma$ ) on the recombinant interleukin- $1 \beta(r I L-1 \beta)$ stimulated release of collagenase from rheumatoid adherent synovial cells*

\begin{tabular}{|c|c|c|c|c|}
\hline \multirow{2}{*}{$\begin{array}{l}r l L-1 \beta \\
(n g / m l)\end{array}$} & \multirow{2}{*}{$\begin{array}{l}r I F N \gamma \\
(U / m l)\end{array}$} & \multicolumn{3}{|c|}{ Collagenase activity $(\mathrm{U} / \mathrm{ml})$} \\
\hline & & Patient 6 & Patient 3 & Patient 9 \\
\hline $\begin{array}{l}0.00 \\
0.00\end{array}$ & $\begin{array}{r}0 \\
10000\end{array}$ & $\begin{array}{l}<0.01 \dagger \\
<0.01\end{array}$ & $\begin{array}{l}<0.01 \\
<0.01\end{array}$ & $\begin{array}{r}0.02 \\
<0.01\end{array}$ \\
\hline $\begin{array}{l}0.03 \\
0.03 \\
0.03\end{array}$ & $\begin{array}{r}0 \\
100 \\
10000\end{array}$ & $\begin{array}{r}0.11 \\
0.03 \\
<0.01\end{array}$ & $\begin{array}{r}0.01 \\
<0.01 \\
<0.01\end{array}$ & $\begin{array}{l}<0.01 \\
<0.01 \\
<0.01\end{array}$ \\
\hline $\begin{array}{l}0.30 \\
0.30\end{array}$ & $\begin{array}{r}0 \\
10000\end{array}$ & $\begin{array}{l}0.52 \\
0.07\end{array}$ & $\begin{array}{r}0.08 \\
<0.01\end{array}$ & $\begin{array}{l}4 \cdot 70 \\
1.57\end{array}$ \\
\hline
\end{tabular}

*Adherent synovial cells from patients with rheumatoid arthritis were cultured with rIFN $\gamma$ or rIL-1B, or both for three days, and collagenase activities in the culture supernatants were determined as described in 'Materials and methods'.

tValues are means of duplicate determinations. Agreement between duplicates was $\pm 10 \%$ of the mean.

activity except for one sample (patient 6) (table 2 ). On the other hand, $0.3 \mathrm{ng} / \mathrm{ml}$ of $\mathrm{rIL}-1 \beta$ clearly induced the release of collagenase activity in all instances. This rIL-1 $\beta$ induced release of collagenase activity was effectively reduced by either $10^{2}$ or $10^{4} \mathrm{U} / \mathrm{ml}$ of rIFN $\gamma$ (table 2).

\section{Discussion}

This study shows some of the regulatory effects of IFN $\gamma$ on the growth and functions of adherent synovial fibroblast-like cells from patients with RA by using IFN $\gamma$ derived from recombinant DNA: rIFN $\gamma$ inhibited not only cell proliferation in most samples, irrespective of their level of prostaglandin synthesis, but also the rIL- $1 \beta$ induced prostaglandin $E_{2}$ release from all these cell samples. In addition, it also reduced the rIL-1 $\beta$ induced collaganese release from these synovial cells.

This is the first demonstration of the inhibitory effect of rIFN $\gamma$ on the growth of rheumatoid synovial fibroblast-like cells, although there are a few reports which show the antiproliferative effects of rIFN $\gamma$ against dermal fibroblasts established from skin explants, ${ }^{28}$ and transformed fibroblastic cell lines. ${ }^{31}$ In contrast with these results, Brinckerhoff and Guyre reported that $\mathrm{rIFN} \gamma$ increased the proliferation of synovial fibroblasts in culture. ${ }^{25}$ One possible explanation of the various results may be differences of cell properties and cell population in culture, which depend on cell-donor individuality, passage number, and so on. Even in our own preliminary tests, both WI-38, a well known fibroblastic cell line resistant to IFN $\gamma,{ }^{31}$ and one out of every two synovial cell samples obtained from patients with non-inflammatory joint diseases, showed slight increases in proliferation in response to low doses of rIFNy (unpublished observation). All the samples of adherent synovial fibroblast-like cells in this study were obtained from patients with classical or definite rheumatoid arthritis, ${ }^{23}$ and six of nine were clearly sensitive to the antiproliferative effect of rIFN $\gamma$ when used at the second to fourth passages. Thus we conclude that at least for rheumatoid synovial fibroblast-like cells rIFN $\gamma$ acts as a decelerator of cell proliferation in most instances. Nevertheless, the extent of the inhibition of proliferation by $\operatorname{rIFN} \gamma$ was variable from sample to sample in our study. For a more precise analysis of these variations and of the discrepancy between studies further experiments with isolated subpopulations of adherent synovial cells would be needed.

Blocking of rIL-1 $\beta$ induced prostaglandin $E_{2}$ release by rIFN $\gamma$ has been reported for human peripheral monocytes. ${ }^{32}$ Our study shows the inhibition by rIFN $\gamma$ of rIL-1 $\beta$ induced prostaglandin release from rheumatoid synovial fibroblast-like cells. On the other hand, Amento et al reported an example in which rIFN $\gamma$ influenced neither the basal release nor the crude monokine preparation-stimulated release of prostaglandin $\mathrm{E}_{2}$ from cultured synovial cells collected from a patient with RA. ${ }^{26}$ The discrepancy between their results and ours might be attributable to differences between the stimuli used, because the regulatory effects of rIFN $\gamma$ on prostanoid release from human monocytes or murine macrophages have been shown to depend largely on the nature of the stimulus. ${ }^{32-35}$ Alternatively, the discrepancy might again be explained by differences in the properties of synovial cells, perhaps due to differences in the inflammatory condition of cell donors, because the extent of the inhibition of $\mathrm{rL}-1 \beta$ stimulated prostaglandin $\mathrm{E}_{2}$ release by $\operatorname{rIFN} \gamma$ has been shown to correlate negatively with the erythrocyte sedimentation rate of cell donor patients (unpublished observation).

Interleukin-1 has been shown to activate phospholipase $A_{2}$, generally believed to be a rate limiting enzyme in the generation of prostanoids, in rat fibroblasts ${ }^{36}$ and rabbit chondrocytes. ${ }^{37}$ Furthermore, Boraschi et al, who used zymosan stimulated macrophages, suggested that the inhibitory effect of IFN $\gamma$ on prostanoid release was at the level of phospholipase $A_{2}{ }^{33}$ In fact, our finding that rIFN $\gamma$ inhibited the release of 6-ketoprostaglandin $\mathrm{F}_{1 \iota}$ and thromboxane $B$ as well as prostaglandin $E_{2}$ to a similar extent suggests that rIFN $\gamma$ exerts its inhibitory action at or before cyclo-oxygenase on the eicosanoid metabolic pathway. Growth control by endogenously produced prostaglandin $\mathrm{E}_{2}$ is well reported. ${ }^{38}$ The inhibition of prostanoid release by IFN $\gamma$, however, does not seem to have any direct correlation with its antiproliferative effect in our system because $(a)$ rIFN $\gamma$ inhibited cell proliferation without influencing the basal rate of prostaglandin $E_{2}$ release, and $(b)$ neither the addition of indomethacin, a potent cyclooxygenase inhibitor, nor rIL-1 $\beta$ influenced the antiproliferative effect of rIFN $\gamma$. Although the mechanisms are not fully understood, it is considered that the antiproliferative effects of interferons are related to their ability to lengthen all phases of the cell cycle. ${ }^{1}$

Another finding in this study is the inhibition by rIFN $\gamma$ of rIL- $1 \beta$ induced release of collagenase activity from rheumatoid adherent synovial cells, though detailed investigations have yet to be done because of the fairly high concentration of $\mathrm{rIL}-1 \beta$ required to induce collagenase release. The inhibitory effect of rIFN $\gamma$ on fibroblast collagen synthesis has been reported by several workers. ${ }^{26} 2839$ It is interesting to mention that the synthesis of both a protease and its substrate-namely, collage- 
nase and collagen, are both controlled by the same lymphokine, IFN $\gamma$. Although the sites of regulation by IFN $\gamma$ in collagenase release are unknown at present, it is suggested that IFN $\gamma$ blocks the transcriptional step of collagen synthesis. ${ }^{39}$

The most important implication of these results concerns the role of IFN $\gamma$ in the pathogenesis of RA. Rheumatoid synovial membrane organises into a replicating mass of tissue, or pannus, which is activated by IL-1 to destroy cartilage and bone by releasing mediators which degrade tissue. ${ }^{21} 22$ Our results suggest that IFN $\gamma$ might contribute to retarding or terminating the progression of these destructive processes in rheumatoid joints by inhibiting synovial cell proliferation and IL-1 induced release of prostaglandins and collagenase. Antagonism by IFN $\gamma$ of IL-1 stimulated bone resorption, ${ }^{40} 41$ interleukin-4 induced $^{42}$ or Epstein-Barr virus induced ${ }^{43} \mathrm{~B}$ cell activation, as reviewed by Browning, ${ }^{44}$ might also be indicative of a down-regulatory role for IFN $\gamma$. Although it is essential to consider the overall role of IFN $\gamma$, including effects such as immunostimulation by enhancement of class II antigen expression $^{2}{ }^{3}$ or possible IL-1 production, ${ }^{45}$ our results seem to provide a new perspective of the regulatory role of IFN $\gamma$ in RA.

1 Borden E C, Ball L A. Interferons: biochemical, cell growth inhibitory, and immunological effects. Prog Hematol 1981 12: 299-339.

2 Friedman R M, Vogel S N. Interferons with special emphasis on the immune system. Adv Immunol 1983; 34: 97-140.

3 Rosa F, Fellous M. The effect of gamma-interferon on MHC antigens. Immunology Today 1984; 5: 261-2.

4 Anonymous. What triggers autoimmunity? [Editorial]. Lancet 1985; i: 78-9.

5 Obert H J, Hofschneider P H. Interferon bei chronischer Polyarthritis. Dtsch Med Wochenschr 1985; 110: 1766-9.

6 Seitz M, Manz G, Franke M, Einsatz von recombinantem Human-Interferon Gamma bei Patienten mit rheumatoider Arthritis. Z Rheumatol 1986; 45: 93-9.

7 Lemmel E M, Franke M, Gaus W, et al. Results of a phase-II clinical trial on treatment of rheumatoid arthritis with recombinant interferon-gamma. Rheumatol Int 1987; 7 : 127-32.

8 Hasler F, Bluestein H G, Zvaifler N J, Epstein L B. Analysis of the defects responsible for the impaired regulation of Epstein-Barr virus-induced B cell proliferation by rheumatoid arthritis lymphocytes. I. Diminished gamma interferon toid arthritis lymphocytes. I. Diminished gamma interferon production in response
Med 1983; 157: 173-88.

9 Combe B, Pope R M, Fischbach M, Darnell B, Baron S, Talal N. Interleukin-2 in rheumatoid arthritis: production of and response to interleukin-2 in rheumatoid synovial fluid, synovial tissue and peripheral blood. Clin Exp Immunol 1985; 59: 520-8.

10 Lotz M, Tsoukas C D, Fong S, Dinarello C A, Carson D A, Vaughan J H. Release of lymphokines after infection with Epstein-Barr virus in vitro. II. A monocyte-dependent inhibitor of interleukin 1 downregulates the production of interleukin 2 and interferon- $\gamma$ in rheumatoid arthritis. of Immunol 1986; 136: 3643-8.

11 Malaise M G, Franchimont P. Defective in vitro $\gamma$-interferon production in rheumatoid arthritis. Arthritis Rheum 1987; 30: $230-1$

12 Seitz N, Napierski I, Augustin R, Hunstein W, Kirchner H. Reduced production of interferon alpha and interferon gamma in leukocyte cultures from patients with active rheumatoid arthritis. Scand F Rheumatol 1987; 16: 257-62.

13 Ridley M G, Panayi G S, Nicholas N S, Murphy J. Mechanisms of macrophage activation in rheumatoid arthritis: the role of gamma-interferon. Clin Exp Immunol 1986; 63: 587-93.

14 Husby G, Williams R C Jr. Immunohistochemical studies of interleukin-2 and $\gamma$-interferon in rheumatoid arthritis. Arthritis Rheum 1985; 28: 174-81.

15 Firestein G S, Zvaifler N J. Peripheral blood and synovia fluid monocyte activation in inflammatory arthritis. II. Low levels of synovial fluid and synovial tissue interferon suggest that $\gamma$-interferon is not the primary macrophage activating factor. Arthritis Rheum 1987; 30: 864-71.

16 Cesario T C, Andrews B S, Martin D A, et al. Interferon in synovial fluid and serum of patients with rheumatic disease. Theumatol 1983; 10: 646-50.
17 DeGre $M$, Mellbye $\mathrm{OJ}$, Clarke-Jenssen O. Immune interferon in serum and synovial fluid in rheumatoid arthritis and in serum and synovial fluid in rheumatoid arthritis

18 Wood D D, Ihrie E J, Dinarello C A, Cohen P L. Isolation of an interleukin-1-like factor from human joint effusions. Arthritis Rheum 1983; 26: 975-83.

19 Waalen K, Duff G W, Førre O, Dickens E, Kvarnes L, Nuk $G$. Interleukin 1 activity produced by human rheumatoid and normal dendritic cells. Scand $\mathcal{f}$ Immunol 1986; 23 : 365-71.

20 Miyasaka N, Sato K, Goto M, et al. Augmented interleukin-1 production and HLA-DR expression in the synovium of rheumatoid arthritis patients. Possible involvement in joint destruction. Arthritis Rheum 1988; 31: 480-6.

21 Dayer J M, de Rochemonteix B, Burrus B, Demczuk S Dinarello C A. Human recombinant interleukin 1 stimuDinarello $C A$. Human recombinant interleukin 1 stimulates collagenase and prostaglandin $\mathrm{E}_{2}$ production
human synovial cells. $\mathcal{F}$ Clin Invest $1986 ; 77: 645-8$.

22 Dukovich M, Severin J M, White S J, Yamazaki S, Mizel $S$ B. Stimulation of fibroblast proliferation and prostaglandin production by purified recombinant murine interleukin 1. Clin Immunol Immunopathol 1986; 38: 381-9.

23 Ropes M W, Bennett G A, Cobb S, Jacox R, Jessar R A. 1958 revision of diagnostic criteria of rheumatoid arthritis. Arthritis Rheum 1959; 2: 16-20.

24 Dayer J M, Krane S M, Russell G G, Robinson D R Production of collagenase and prostaglandins by isolated Production of collagenase and prostaglandins by isolated adherent rheumatoid

25 Brinckerhoff C E, Guyre P M. Increased proliferation of human synovial fibroblasts treated with recombinant immune interferon. F Immunol 1985; 134: 3142-6.

26 Amento E P, Bhan A K, McCullagh K G, Krane S M. Influence of gamma interferon on synovial fibroblastlike cells. Ia induction and inhibition of collagen synthesis. f Clin Invest 1985; 76: 837-48.

27 Schmidt J A, Mizel S B, Cohen D, Green I. Interleukin 1, a potential regulator of fibroblast proliferation. $\mathcal{f}$ Immunol 1982; 128: 2177-82.

28 Duncan M R, Berman B. y Interferon is the lymphokine and $B$ interferon the monokine responsible for inhibition of fibroblast collagen production and late but not early fibroblast collagen production and late but not early
fibroblast proliferation. $\mathcal{J} E x p$ Med 1985; 162: 516-27.

29 Galelli A, Garrec Y L, Chedid L, Lefrancier P, Derrien M, Level $M$. Macrophage stimulation in vitro by an inactive muramyl dipeptide derivative after conjugation to a multipoly (DL-alanyl)-poly (L-lysine) carrier. Infect Immun 1980; 28: 1-5.

30 Terato K, Hashida R, Miyamoto $\mathrm{K}$, et al. Histological, immunological and biochemical studies on type II collageninduced arthritis in rats. Biomedical Research 1982; 3: 495-505.

31 Sugarman B J, Aggarwal B B, Hass P E, Figari I S, Palladino $M$ A Jr, Shepard H M. Recombinant human tumor $M$ A Jr, Shepard $H$ M. Recombinant human tumor necrosis factor- $\alpha$ : effects on proliferation of normal
transformed cells in vitro. Science 1987; 230: 943-5.

32 Browning J L, Ribolini A. Interferon blocks interleukin 1 induced prostaglandin release from human periphera monocytes. I Immunol 1987; 138: 2857-63.

33 Boraschi D, Censini S, Bartalini M, Tagliabue A. Regulation of arachidonic acid metabolism in macrophages by immune and nonimmune interferons. $\mathcal{F}$ I mmunol 1985; 135: 502-5

34 Hamilton T A, Rigsbee J E, Scott W A, Adams D O $\gamma$-Interferon enhances the secretion of arachidonic acid metabolites from murine peritoneal marcrophages stimulated with phorbol diesters. F Immunol 1985; 134: 2631-6.

35 Nichols F C, Garrison S W. Interferon- $\%$ potentiation of lipopolysaccharide-induced eicosanoid release from human monocytes. F Interferon Res 1987; 7: 121-9.

36 Godfrey R W, Johnson W J, Hoffsterin S T. Interleukinstimulation of phospholipase activity in rat synovial fibroblasts. Possible regulation by cyclooxygenase products. Arthritis Rheum 1988; 31: 1421-8.

37 Chang J, Gilman S C, Lewis A J. Interleukin 1 activates phospholipase $A_{2}$ in rabbit chondrocytes: a possible signal for IL 1 action. I Immunol 1986; 136: 1283-7.

38 Pastan I H, Johnson G S, Anderson W B. Role of cyclic nucleotides in growth control. Annual Review of Bio chemistry 1975; 44: 491-522.

39 Rosenbloom J, Feldman G, Freundlich B, Jimenez S A Transcriptional control of human diploid fibroblast collagen synthesis by $\gamma$-interferon. Biochem Biophys Res lagen synthesis by $\gamma$-interfer
Commun 1984; 123: 365-72.

40 Gowen M, Mundy G R. Actions of recombinant interleukin 1 interleukin 2 and interferon- $\gamma$ on bone resorption in 1 , interleukin 2 , and interferon- $\gamma$ on

41 Hoffman N O, Klaushofer K, Koller K, Kock A, Peterlik M Luger T A. ETAF and recombinant murine IL-1 induced bone resorption is blocked by $2-\gamma$-IFN. F Invest Dermato 1986; 86: 340.

42 Coffman $R$ L, Carty J. A T cell activity that enhances polyclonal IgE production and its inhibition by interferon- $\gamma$. $\mathcal{I}$ Immunol 1986; 136: 949-54.

43 Lotz M, Tsoukas C D, Curd J G, Carson D A, Vaughan J H Effects of recombinant human interferons on rheumatoid arthritis B lymphocytes activated by Epstein-Barr virus. I Rherumatol 1987; 14: 42-5.

44 Browning J. Interferons and rheumatoid arthritis: Insigh into interferon biology? Immunology Today 1987; 8: 372-4.

45 Boraschi D, Censini S, Tagliabue A. Interferon- $\gamma$ reduces macrophage-suppressive activity by inhibiting prostaglandin $\mathrm{E}_{2}$ release and inducing interleukin 1 production. f Immunol 1984; 133: 764-8. 